Gabriel Watts

Centre for Advanced Studies

in the Humanities - Human Abilities,

Freie Universität Berlin

gabriel.watts@sydney.edu.au
Original Scientific Paper

UDC 165 Хјум Д.

165.195

\title{
READING HUME ON THE PASSIONS
}

\begin{abstract}
This paper provides a reception history of Book Two of the Treatise - Of the passions - as well as an attempt to reconcile Hume's ambitions to systematicity in Book Two with the distracted and distracting nature of the text. We currently have, I think, a good sense of the philosophical importance of Book Two within Hume's science of human nature. Yet we have not made much progress on understanding Book Two on its own terms, and especially why Book Two so often seems on the verge of falling into an explanatory heap. I aim to rectify this situation by giving a reading of Book Two that makes sense of the philosophical importance of Hume's system of the passions, yet also explains why he encounters so many difficulties in setting out his system; such that he is often forced to stretch his explanations to the very edge of the credible. I contend that Hume's system of the passions is best viewed as an unstable explanatory compound, one that progressively dissolves as Hume's explanatory intentions become increasingly ambitious.
\end{abstract}

Keywords: Hume, Passions, Emotions, Treatise, Animals

\section{Introduction}

Of the three books that comprise Hume's A Treatise of Human Nature, it is Book Two, 'Of the passions', that most reads as if it was written by a man in his mid-twenties. At one point Hume says that ' $\mathrm{t}$ ] he different stations of life influence the whole fabric [of a person], internal and external' (T 2.3.1.9, SBN 402) and it is difficult not to apply this to Hume's own concerns, intellectual and otherwise. He is very interested to understand the origin of our desire for riches and power (T 2.1.10, 2.2.5; SBN 309-316, 357-365), and he is acutely sensitive to the shame felt by those of 'narrow circumstances' (although not especially empathetic) (T 2.1.11.14, SBN 322). Sexually-charged relationships are frequently mined for examples ( $\mathrm{T}$ 2.1.11.19, 2.2.11, 2.3.4.3; SBN 324, 394-6, 420), as well as other 'curious phenomena' such as the weakening of the maternal bond after a second marriage ( $\mathrm{T}$ 2.2.4.9, SBN 355). And this is without even mentioning the many inconsistencies - both terminological and substantive - that arise from the tension between the young Hume's excessive desire to explain and his commitment to producing a system of the passions that is 'so simple' as to compel his reader's assent ( $T$ 2.1.12.9, 
2.2.12.1; SBN 327-8, 397). Indeed Book Two is so stuffed with examples, often requiring searching and unwieldly explanations, that it is perhaps a minor miracle that Hume's philosophy of the passions has come to be seen as especially important for understanding his intentions in the Treatise, if not his philosophical intentions on the whole.

In this paper I take up the question of the explanatory unity of Book Two of the Treatise; or rather, its seeming lack thereof. I begin by giving a reception history of Book Two. My aim here is to show that Hume's system of the passions was initially regarded as a distracted and distracting text with no strong connection to the rest of his philosophy, and that our current sense of Book Two's philosophical importance has largely been shaped in response to this false charge: either by reading Book Two in light of Hume's concerns in Book One, Book Three, or both; or in light of broader philosophical concerns regarding the government of the passions. However, given that we now have a well-developed sense of the value and importance of Book Two within these contexts, I suggest that we examine Book Two on its own terms, and see if we cannot find unity of purpose amongst Hume's intentions for his philosophy of the passions, considered as an important part of his science of man in its own right.

My claims are schematic, but what I suggest is that the philosophy of the passions that Hume sets out in Book Two is shaped by three distinct intentions. Primarily, Hume's philosophy of the passions is an attempt to explain why increasing affluence in any society necessitates the establishment of civil government. Most of Hume's key analyses and innovations in Book Two, I claim, are well-understood as having been originally invented to this purpose. Secondarily, Hume's philosophy of the passions is an attempt to draw sense-based theories of mankind's natural benevolence within the framework that he had invented to account for the origin of civil government. However, as it turns out, the system of the passions that Hume had invented to explain the origin of civil government is not especially well-suited to this purpose, and most of the explanatory difficulties that Hume encounters in Book Two can be understood in light of his attempt to stretch his philosophy of the passions beyond its original purpose.

I then suggest that these primary and secondary intentions are subsumed under a third, which gives Hume's philosophy of the passions its unity of purpose. Namely, Hume's philosophy of the passions is an attempt to explain human sociability using principles that are observed to operate throughout the whole of 'sensitive creation'. This was part of Hume's design in first developing his system of the passions, and it motivates him to explain our natural benevolence using the same system. However, Hume's prosecuting this plan across the whole of Book Two requires him to explain the origin of curiosity - a sociable passion that we do not share with animals - using principles that are common to both man and beast. Hume is able to do so, I claim, but only at the cost of obscuring his initial distinction between the 'direct' and 'indirect' passions. 


\section{The Reception of Hume's Philosophy of the Passions}

A good place to begin a reception history of Hume's philosophy of the passions is with Hume's own reworking of Book Two in A Dissertation on the Passions, which he published as part of his Four Dissertations (1757). The Dissertation is a truncated version of the text of Book Two of the Treatise: it is notably shorn of examples, has some structural changes, and seems to make a few conceptual adjustments. ${ }^{14}$ With its final paragraph, Hume sums up his aims for the Dissertation with the remark that:

I pretend not to have here exhausted this subject. It is sufficient for my purpose, if I have made it appear, that, in the production and conduct of the passions, there is a certain regular mechanism, which is susceptible of as accurate a disquisition, as the laws of motion, optics, hydrostatics, or any part of natural philosophy.

(DP 6.19)

While we ought not to suppose that Hume's overall purpose with the Dissertation was the same as with Book Two of the Treatise, I think it is safe to assume that Hume intended both tracts to show that the 'production' and 'conduct' of the passions can be traced to 'regular' mental mechanisms, and that these are 'susceptible of as accurate a disquisition, as the laws of motion, optics, hydrostatics, or any part of natural philosophy'.

Indeed that this was amongst Hume's aims with Book Two has never really been in doubt. What has been vigorously debated, however, is the philosophical point, and value, of Hume's attempting to do so. As regards his attempt to show that the 'conduct' of our passions is not the product of a faculty of practical 'reason', but is entirely reducible to mechanical principles, Hume has been severely chastened; both for his execution and his intentions. Thomas Reid regarded Hume's denial of rational principles of action encapsulated in Hume's infamous dictum that 'reason is, and ought only to be the slave of the passions' (T 2.3.3.4, SBN 414-5) - as hopelessly confused, ${ }^{15}$ a judgement that many others have shared. ${ }^{16}$ T.H. Green goes even further. In his general introduction to Books Two and Three of the Treatise, Green

14 For the only extended study of the A Dissertation on the Passions in relation to Book Two of the Treatise (that I know of), see Amyas Merivale, Hume on Art, Emotion, and Superstition (New York: Routledge, 2018), esp. 128-44; for a detailed account of the textual truncations, see Tom Beauchamp, "Introduction: A History of Two Dissertations" in David Hume, A Dissertation on the Passions: The Natural History of Religion: A Critical Edition, ed. Tom Beauchamp (Oxford: Oxford University Press, 2007), 1-cxvi.

15 Thomas Reid, Essays on the Active Powers of Man, eds. Knud Haakonssen and James A. Harris (Edinburgh: Edinburgh University Press, 2010), 157; see also 135-6, 153.

16 Even those who are otherwise favourably disposed towards Hume's moral theory have been relatively unimpressed. See here, J.L. Mackie, Hume's Moral Theory (London: Routledge and Keagan Paul, 1980), 44-63. 
characterises Hume's mechanistic account of volitional actions as a deliberate attempt to 'degrade' morality by pouring 'solvent' on reason. ${ }^{17}$

Green is similarly dismissive of Hume's account of the causal origins of various passions, the exposition of which makes up the bulk of Book Two. ${ }^{18}$ Green presents Book Two - the very work he is introducing - as proceeding from false assumptions, and, as a result, as being full of explanatory 'subterfuges' 19 . An especially entertaining example concerns Hume's attempt to explain the 'indirect' origin of pride and humility, as well as love and hatred, from what he (Hume) calls a double relation of ideas and impressions ${ }^{20}$. Here Green wryly observes that to make his explanation work, Hume introduces a principle of association between impressions which is similar to, but slightly different from, the principle of association between ideas that he had introduced in Book One. This is 'somewhat strange', Green says, given that Hume had previously claimed that there was no essential difference between impressions and ideas, but rather that ideas were just phenomenally weaker 'copies' of impressions: ${ }^{21}$ for, if this were the case, ought any principle of association between ideas apply equally to impressions? Indeed, almost any objection that might be levelled at the coherence of Hume's philosophy of the passions can be found in Green's introduction; the writing of which Green described as an 'irksome labour' whose chief goal was to show that there was nothing of value in Hume's 'anachronistic system'22.

Interestingly, Green's view of Hume's philosophy of the passions as containing nothing much of value was endorsed by Norman Kemp Smith, who otherwise set himself in direct opposition to the Reid-Green interpretation of Hume as a sceptical philosopher. ${ }^{23}$ On the Reid-Green reading, as Kemp Smith describes it, 'Hume's teaching is sheerly negative, being in effect little more than a reductio ad absurdum of the principles which Hume's predecessors, and Hume himself, have followed in their enquiries' 24 . To those who accepted this reading of Hume's philosophy, Hume's scepticism in morals was of a piece with his scepticism in epistemology, and his overall

17 T. H. Green, "Introduction to Moral Part of the Treatise" in The Philosophical Works of David Hume, 4 vols., eds. T. H. Green and T. H. Grose (London: Longmans, Green, and Co, 1874-5), vol 2 (1874), 1, 48-54.

18 Green, 32-48.

19 Green, 37.

20 See here, Green, 35-42.

21 Green, 36.

22 Green, 71.

23 See Norman Kemp Smith, The Philosophy of David Hume (New York: Palgrave, Macmillan, 1941) (The Philosophy of David Hume), 3-14; Norman Kemp Smith, "The Naturalism of David Hume (I)", Mind 14.54 (April 1905), 149-73; and Norman Kemp Smith, "The Naturalism of David Hume (II)", Mind 14.55 (July 1905), 335-47. See also on this point, John Laird, Hume's Philosophy of Human Nature (London: Routledge, 1932).

24 Kemp Smith, The Philosophy of David Hume, 3. 
philosophy was a potent intellectual solvent, to be handled very carefully, and only as necessity required.

Against this, Kemp Smith claimed that the 'correct reading' of Hume's purposes with his sceptical arguments was to show that our most fundamental beliefs - our belief in the existence of external objects, in our personal identity, and in the rational warrant of our arguments - are the products of 'feeling, not reason or understanding ... and therefore also not ideas - at least not 'ideas' as hitherto understood'25. Hume's most 'general title' for such 'feelings', Kemp Smith claimed, is "passion' ... and belief, he teaches, is a passion" ${ }^{26}$. This being the case, Kemp Smith asserted that:

The maxim which is central in his ethics - 'Reason is and ought to be the slave of the passions' - is no less central in his theory of knowledge, being there the maxim: 'Reason is and ought to be subordinate to our natural beliefs. ${ }^{27}$

It was this general disposition of thought that Kemp Smith coined Hume's 'naturalism', and he claimed that it represented Hume's fundamental philosophical disposition, against which his sceptical arguments, as well as everything else in his philosophy, ought to be understood.

Kemp Smith's conception of Hume as a fundamentally naturalistic philosopher has been widely influential. As such, it is noteworthy that Kemp Smith himself had a low opinion of Book Two. In a section of The Philosophy of David Hume with the amusing title, 'Unsatisfactory Features of the Argument and Exposition in Book II, Kemp Smith writes (and I quote at length):

For several reasons Book II, as regards sequence and mode of exposition, is the least satisfactory of the three books which constitute the Treatise ... More than a third of Book II is employed in the treatment of four passions which have no very direct bearing upon Hume's ethical problems, and play indeed no really distinctive part in Hume's system - pride, humility, love and hatred ... In so far as Hume's purpose in discussing these four passions is to support his thesis that the laws of association play a rôle in the mental world no less important than that of gravity in the physical world, his argument does connect itself with Book I ... But even so, he bewilders his readers by introducing two special laws of association (one of them between impressions!) additional to those mentioned in Book I, and by an over-ingenious elaboration of his argument. This is, indeed, the most outstanding instance in which Hume's secondary plot - a statics and dynamics of the mind - has broken in upon, and has unhappily thrown into confusion, the requirements proper to his main programme. ${ }^{28}$

25 Kemp Smith, The Philosophy of David Hume, 11.

26 Kemp Smith, The Philosophy of David Hume, 11.

27 Kemp Smith, The Philosophy of David Hume, 11.

28 Kemp Smith, The Philosophy of David Hume, 160-1. 
This passage is worth quoting at length because it reveals that Kemp Smith's disagreement with Green and others as to the merits of Hume's philosophy was a disagreement over the merits of Hume's epistemology. Regarding the philosophy of the passions that Hume develops in Book Two, Kemp Smith mostly agreed that it was a 'hindrance ${ }^{29}$.

The passage above is also useful insofar as Kemp Smith's criticisms of Book Two served as grist to the mill for a later generation of scholars, who while accepting Kemp Smith's thesis that Hume's fundamental philosophical disposition was naturalistic, rather than sceptical - set out to prove that Kemp Smith had underestimated the importance of Hume's philosophy of the passions to his overall philosophy of human nature. Here Páll Árdal took it upon himself to demonstrate the crucial importance of the passions of pride, humility, love and hatred to Hume's moral philosophy - in particular their close connection to moral sentiments. ${ }^{30}$ While Nicholas Capaldi sought to show that Hume's 'statics and dynamics of the mind' was not a 'secondary plot', as Kemp Smith had claimed, but was the primary plot, and that Hume's causal account of the origins of our passions played a leading role. ${ }^{31}$

More precisely, Capaldi argued that Kemp Smith's thesis regarding 'the primacy of feeling in Hume' had the 'unfortunate' effect of making Hume's philosophy 'even more irrationalist than in the Reid interpretation'32. Kemp Smith had made this error, Capaldi thought, because he had failed to see 'the real connection of psychology and logic in Hume'33. However, once one came to see that Hume's epistemological naturalism was grounded in his 'Newtonian' thesis regarding the role that 'laws of association' play in the mental world, then one would come to see that Hume's theory that our passions arise from various principles of mental association is an essential part of Hume's science of human nature, not a hindrance for Hume's readers to overcome. ${ }^{34}$ Indeed, by 1975 , Capaldi could write that:

Book II of the Treatise is in many respects the most important for exemplifying the major themes of Hume's philosophy. By its discussion of the mechanism of association it serves as a confirmation of Hume's explanation of the mechanics of causal belief. At the same time, it prepares the way for Hume's moral theory by explaining the

29 Kemp Smith, The Philosophy of David Hume, 161.

30 See esp. Páll Árdal, Passion and Value in Hume's Treatise (Edinburgh University Press, 1966), 109-47.

31 Nicholas Capaldi, David Hume, The Newtonian Philosopher (Boston: Twayne Publishers, 1975), 130-50.

32 Capaldi, 229.

33 Capaldi, 229.

34 See here, Capaldi, 49-70. In arguing like this Capaldi can be seen to be following Laird, who was the first to stress the significance of Newton for Hume, or that 'Hume meant, in short, to become the Newton of the Human Mind': Laird, 29. 
mechanism of sympathy. Again, it serves as an explanation for the concept of the self which proved so problematic in Book I. Finally, by outlining his theory of human motivation Hume completes his project of undermining both the rationalist model in general and rationalist moral theories. Thus, an understanding of the passions is essential for an understanding of all the philosophical issues in Hume's Treatise. ${ }^{35}$

This claim, now forty-five years old, gives a good general description of the scholarly outlook that has characterised the study of Book Two ever since; for the details of which I refer the reader to Elizabeth Radcliffe's excellent overview of the current state of the art in her article 'Hume's Psychology of the Passions' (2015). ${ }^{36}$ Instead I want to focus on one particular line of argument that has come to the fore as a means of assessing, and asserting, the importance of Hume's philosophy of the passions as a distinctive concern within Hume's philosophy of human nature. This line of argument is nicely foreshadowed by Capaldi's claim that with Book Two 'Hume completes his project of undermining both the rationalist model in general and rationalist moral theories'; yet its first sustained articulation is given in Annette Baier's book A Progress of Sentiments (1991). ${ }^{37}$

Baier's fundamental assertion is that Books One and Two of the Treatise are linked together by a narrative dimension. Baier's core claim - in her own words - is that with his depiction of his skeptical crisis at the end of Book One, Hume:

enacts for us the turn he wants us to imitate, a turn from a one-sided reliance on intellect and its methods of proceeding to an attempt to use, in our philosophy, all the capacities of the human mind: memory, passion and sentiment as well as a chastened intellect. That is what Hume attempts from Book Two onwards - not only are passions his topic there, but his approach to them is to be guided by experienceinformed passion, and he recommends that his readers indulge their sentiments when they join him in his pursuit of philosophy "in this careless manner". 38

On Baier's view, Hume's Treatise is something of a three-act epistemological drama, in that, '[1]ike Descartes in his Meditations, so Hume in his Treatise stages a thinker's dramatic development from inadequate and doubt-inviting

35 Capaldi, 130.

36 Elizabeth S. Radcliffe, "Hume's Psychology of the Passions: The Literature and Future Directions," Journal of the History of Philosophy, 53:4 (2015): 565-605.

37 For similar ideas, articulated at a similar time see, Amélie Oksenberg Rorty, "Pride produces the idea of self': Hume on moral agency," Australasian Journal of Philosophy, 68:3 (1990): 255-269.

38 Annette Baier, A Progress of Sentiments: Reflections on Hume's Treatise (Cambridge, MA: Harvard University Press, 1991), 1. 
approaches to more satisfactory reflections' ${ }^{39}$. Hume's genius, however, was to have shown that what Baier calls the 'Cartesian' conception of rationality is self-undermining, and that the recognition of this ought to push us towards an 'embodied', 'social' conception of ourselves as rational beings: which is to say, towards a philosophical self-conception that we, and others, endorse upon reflection, and, as such, is capable of withstanding skeptical challenges of the type that Hume encounters at the end of Book One. ${ }^{40}$

Baier herself could be rather careless with the details of Hume's philosophy. Yet she gives a compelling account of the general intellectual thrust of the Treatise, and a number of later scholars have stepped in to fill out the specifics. ${ }^{41}$ The most notable adjustment of Baier's basic position, in my view, is the recent turn towards understanding the relationship between Books One and Two of the Treatise in light of the broader philosophical concern with the relation between reason and passion, rather than through Baier's more narrowly epistemological framing. James Harris puts the point succinctly when he says that:

Missing from Baier's account, however, is full acknowledgement of the magnitude of the problem that Hume has created for himself as he moves on to Book Two ... What Hume knew, and what his readers knew, was that the passions were usually taken to be a problem that required reason for its solution. How, without governance by reason, could the passions supply anything other than distraction and disturbance? ${ }^{42}$

Broadly speaking, answers to this question have gone two ways. The answer that Harris, and others, propose is that with Book Two of the Treatise Hume intends show that the passions are capable of governing themselves. ${ }^{43}$ More

39 Baier, vii.

40 For Baier's final articulation of her position see Annette Baier, "Reflexivity and Sentiment in Hume's Philosophy", in The Oxford Handbook of Hume, ed. Paul Russell (Oxford: Oxford University Press, 2016), 54-9.

41 See here: Lilli Alanen, "Reflection and Ideas in Hume's Account of the Passions", in Persons and Passions: Essays in Honour of Annette Baier, eds. Joyce Jenkins, Jennifer Whiting, and Christopher Williams (University of Notre Dame Press, 2005) (Persons and Passions), 117-43; Donald Ainslie, "Sympathy and the Unity of Hume's Idea of Self", in Persons and Passions, 143-73; Janet Broughton, "Hume's Voyage" in Persons and Passions, 174-91; for book-length studies in this vein, see Jacqueline Taylor, Reflecting Subjects: Passion, Sympathy, and Society in Hume's Philosophy, (Oxford: Oxford University Press, 2015), and Jay L. Garfield, The Concealed Influence of Custom: Hume's Treatise from the Inside Out, (New York: Oxford University Press, 2019).

42 James A. Harris, “'A Compleat Chain of Reasoning”; Hume's Project in A Treatise of Human Nature, Books 1 and 2", Proceedings of the Aristotelian Society, 109 (2009), (Compleat Chain) 135.

43 See here, Jane L. McIntyre, "Hume's 'New and extraordinary' account of the passions", The Blackwell Guide to Hume's Treatise, ed. Saul Traiger, (Malden, MA: Blackwell, 2006), 199-215; Christopher J. Finlay, Hume's Social Philosophy: Human Nature and Commercial Sociability in A Treatise of Human Nature (Continuum, 2007), 44-157; Taylor, 1-98; see 
precisely, the claim is that Hume deliberately analyses passions that had traditionally been portrayed as socially destructive forces - pride, vanity, the desire for riches and power - and shows them to be mechanically tuned towards pro-social ends on account of our sympathetic 'concern for how others see us, a desire for their love and admiration, [and] an aversion to their hatred and contempt ${ }^{34}$. In this way, Hume is thought to establish the existence of a self-ordering realm of passionate activity. One that is independent, in principle, from the political realm; such that the government of the passions is revealed as being to a considerable extent self-government - 'in the context of the social realm taken as a whole ${ }^{45}$ - rather than political government.

Mikko Tolonen, by contrast, has argued that Hume's basic position on the control of the passions is that there is no 'lasting spontaneous order in a large society to serve self-interest or other passions without a government to redirect their natural course ${ }^{36}$. As such, whatever capacity for selfgovernment the passions might have, it only operates small rudimentary societies, not large civil societies 'in which people are not necessarily related to or even acquainted with each other' ${ }^{2}$. It is Tolonen's view that the principle of sympathy is not sufficient to overcome the challenges that passions create in large societies' ${ }^{3}$ : a point that he thinks Hume makes abundantly clear in Book Three of the Treatise. Thus when it comes to the question of government of the passions, we find that our 'rechanneling the passions through political and moral customs still plays the key role ${ }^{\text {' }}$. It is Tolonen's contention that Hume's focus on our self-liking and self-interested passions in Book Two was intended to set up his Book Three view that the origins of our most important political and moral conventions can be traced to the naturally disruptive consequences of pride, vanity, and self-interest for largescale collective living.

It is not my design to adjudicate between these interpretations here. Other than to say that the social world of Book Two is one in which the conventions that establish the ranks of civil authority are already in a highly developed state. This makes it very difficult to tell whether Hume's presentation of the passions as forming a sympathetically self-regulating economy, governed primarily by considerations of honour and dishonour, respect and contempt,

also James A. Harris, Hume: An Intellectual Biography (Cambridge: Cambridge University Press, 2015), 102-116.

44 Harris, Compleat Chain, 137.

45 Harris, Compleat Chain, 132.

46 Mikko Tolonen, Mandeville and Hume: Anatomists of Civil Society (Voltaire Foundation: Oxford, 2013), 13-4.

47 Tolonen, 13.

48 Tolonen, 22.

49 Tolonen, 22. 
in fact merely reflects the long-established conventions of civil government and polite behaviour that keep the various 'ranks' of individuals in steady place. Yet, whatever the case, there is general agreement that Hume dismisses the notion that a distinct rational principle of authority, such as conscience or practical reason, is required for control of the passions; and that whatever the aims of Hume's theory of the 'indirect' passions were, Hume makes a novel contribution to eighteenth century debates about human sociability.

What this reception history of Book Two makes clear, I hope, is that the last seventy-odd years of scholarship have established the importance and value of Hume's philosophy of the passions, both within his Treatise project and in the context of larger debates over the relationship between reason and the passions. Yet, by the same measure, I think it is safe to say that our current understanding of Hume's intentions with Book Two has been almost entirely imposed from the outside. We have sought to understand Hume's philosophy of the passions in the context of the Treatise as a whole, or as first published, or as part of larger philosophical discussions about the nature of the passions. Not so much on its own terms.

There are perfectly good reasons for this. As we saw, the study of Book Two as an important part of Hume's science of man was initially a response to early assessments of the low philosophical value of Book Two, both from Hume's detractors and his chief defenders, and not only within his Treatise project, but also concerning the general question of how the passions ought to be controlled. As a result of this scholarship, and that which has since built upon it, we have developed a good sense - a fine-grained sense - of what Hume was up to in Book Two. Yet we have not, I think, made much progress on the question of the internal explanatory unity of Hume's philosophy of the passions; or rather, on the question of why Hume's attempt to systematise human feeling and action lacks a clear unity of purpose.

Book Two does, of course, have some notable structuring features, namely Hume's novel division of the passions into those that are 'direct' and those that are 'indirect'. But even this is not a division that Hume makes, or keeps, especially clear. Then there are questions about his inclusion of the will within his treatment of the passions, even though 'properly speaking' it does not belong there ( $\mathrm{T}$ 2.3.1.2, SBN 399), including the question of whether or not he thinks that it is, in fact, a passion (see T 2.3.9.7, SBN 439). There is also his decision to seemingly tack an account of curiosity onto the end of Book Two, because it would have been 'impossible' to have included it 'under any other head ... without danger of obscurity and confusion' (T 2.3.10.1, SBN 448). And what to make of his introduction of 'blended' passions in the middle of his account of love and hatred (T 2.2.6.1, SBN 366)? This certainly seems to be an assertion of a categorical distinction between impressions and ideas; flatly contradicting his earlier claims that these two classes of perceptions are 'essentially the same' and distinguished 
only by their 'liveliness and vivacity' ${ }^{50}$. Jane McIntyre has referred to such phenomena as giving an 'elusive' quality to Book Two, which is a polite way of putting it. ${ }^{51}$ Much more than the other books of the Treatise, if not the rest of Hume's philosophical writings, Book Two gives the appearance of having been worked out as he went along: Reid, Green, and Kemp Smith make a good point when they portray Book Two as both distracted and distracting when read on its own terms.

\section{The Internal Unity of Hume's Philosophy of the Passions}

Still, now that we have a much better sense of the value and importance of Book Two, I want to suggest that we focus our attention on the question of the internal unity of Hume's philosophy of the passions. This is not to say, to be clear, that we should foreground issues of textual exegesis regarding Hume's key distinctions: between direct and indirect passions, passions and sentiments (and emotions), or between calm and violent passions. This is important work, but I doubt that we will ever come to grips with what Hume "really means" when he draws such distinctions, given how careless he is with his terminology; 52 and anyway, to the extent that we might look for unity amongst any of Hume's philosophical writings, our model ought not to be that of a textual puzzle awaiting solution: "Hume's true meaning". Surely Hume himself would not have wanted us to treat his philosophy as a static object. Instead our model should be that of a river. Something fundamentally in motion, but which nevertheless has consistent general features. It is these general points of consistency that I am interested in.

Nor do I mean to say that we ought to study Hume's philosophy of the passions without any reference to his intellectual context, or to his other philosophical writings, and especially to the other two books of the Treatise. This would be to embrace a bizarre sort of interpretive asceticism. Rather, my suggestion is that when we do look to external context, or to Hume's other writings, it is in the service of reading Book Two on its own terms, as compared, say, to using Book Two to either confirm or complete points made in Book One, or as serving as the foundation of the moral theory that he expounds in Book Three. ${ }^{53}$

50 For examination of this point within Hume's broader explanatory framework, see Tamás Demeter, David Hume and the Culture of Scottish Newtonianism Methodology and Ideology in Enlightenment Inquiry (Boston: Brill, 2016), 134-149.

51 McIntyre, 199.

52 This is not to say that Hume's carelessness is not relatively consistent, or sometimes merely a matter of stylistic variation, such that we cannot get a good idea of what he was thinking. But rather that his carelessness leaves enough room to doubt that we could ever settle such questions authoritatively.

53 Hume does say that his philosophy of the passions serves as the 'foundation' of the rest of his science of human nature (T Abstract 3, SBN 646). My point is simply that we are not bound to reading it as such. 
For instance, as Harris, Tolonen, and others have shown, a central concern of Hume's philosophy of the passions is the question of the government of the passions, and that much of what Hume says in Book Two can be seen as setting up, or serving as the psychological foundation for, claims that he wants to make about the origin of government in Book Three; especially as regards mankind's natural capacity to live without government for considerable stretches of time, at least in certain circumstances (see T 3.2.8.1-3, SBN 539-42). Yet we might also see Hume's genealogy of government as being empirically well-founded, independent of his psychology of the passions; given that we have knowledge of (what Hume thinks are) rudimentary societies that exist without civil government, but can also plainly see that most societies establish some kind of sovereign political authority as they grow in size and stature (T 3.2.8.1-3, SBN 539-42). On this reading, Hume's psychology of the passions is an independent (although closely related) attempt to understand the psychological reasons behind the genealogical observation that government becomes 'absolutely necessary' once certain conditions are met (see T 3.2.8.1, SBN 539); and more precisely, why it is that ' $[n]$ othing but an encrease of riches and possessions' can 'oblige' human beings to establish civil magistrates (see T 3.2.8.2, SBN 541).

If we read things this way we can approach Book Two quite differently to how it reads on the page. Here, rather than beginning with Hume's account of pride and humility as phenomenally simple indirect impressions of reflection, we can begin by looking at his explanation of our desire for riches and possessions. In particular, with his claim that 'one of the principal recommendations of riches, and ... the chief reason, why we either desire them for ourselves, or esteem them in others' is the 'secondary satisfaction or vanity' that 'a rich man receives from his possessions' (T 2.2.5.21, SBN 365). This 'secondary satisfaction or vanity' is, of course, an instance of pride. But it is one with an importantly complex aetiology.

For starters, the original feeling of pride that the rich and propertied take in their possessions and riches is itself a rather complicated affair. Such feelings arise, Hume thinks, not simply from their considering the utility of their wealth and property to themselves, or to others, but from their pleasing belief - whether true or false - that they are at 'liberty' to reap whatever advantages they choose, by the use of their riches and property, within the bounds of 'justice and moral equity' (T 2.1.10.1-12, SBN 309-16). Hume's argument for this claim is impossible to unpack here, but it demands, as he acknowledges, an account of the nature of human liberty, and more precisely, of the belief that wealth confers a power to act, or not act, as one pleases (see here T 2.1.10.9, SBN 314). ${ }^{54}$

54 For more on these points see Taylor, 71-98. 
Further, the 'love and esteem' that we have for the rich and powerful is not (for the most part, Hume thinks) a matter of our considering the utility that their possessions and wealth afford them (see here T 2.2.5, SBN 357-65). Rather it is a matter of our sympathising with 'the satisfaction, which this power [to act or not act as one pleases] affords the person, who is possessed of it' ( $\mathrm{T}$ 2.2.5.6, SBN 359). On Hume's theory that both love and hatred, like pride and humility, are caused by a double relation of ideas and impressions, our sympathetic perception of the satisfaction that the rich and propertied take in their liberty to act on their desires naturally causes us to love them. Our esteem for such persons, insofar as we might distinguish esteem from love, is then a mixture of this love with humility, the latter of which being caused by our comparing their possessions and wealth to our own circumstances and finding ourselves wanting (see here T 2.2.10, SBN 389-93).

The 'secondary satisfaction or vanity' that the rich and propertied take in their wealth and possessions is then a further sensation of pride that arises when such persons sympathise with their admirers and perceive the pleasing sentiments of love and esteem that their (own) riches and possessions produce (T 2.2.5.21, SBN 365). Not only this, but in instances where their riches and possessions afford them the power of using other persons as the means to the satisfaction of their desires, this 'vanity of power' is augmented by a further comparative pleasure that arises from their comparing the superiority of their power to that of other rational creatures (T 2.1.10.12, SBN 315-6). Nor is this a throwaway point. Rather, Hume contends that:

supposing it possible to frame statues of such an admirable mechanism, that they cou'd move and act in obedience to the will; 'tis evident the possession of them wou'd give pleasure and pride, but not to such a degree, as the same authority, when exerted over sensible and rational creatures, whose condition, being compar'd to our own, makes it seem more agreeable and honourable. Comparison is in every case a sure method of augmenting our esteem of any thing. A rich man feels the felicity of his condition better by opposing it to that of a beggar.

(T 2.1.10.12, SBN 315-6)

Hume at one point seems to call this particular species of vanity 'ambition', and to suggest that this passion is a species of vanity that is augmented by a malicious desire to subjugate other rational creatures so as to experience and maintain a pleasing comparison (T 2.2.8.14, SBN 378). But, as with many other things, he never makes this clear.

Still, it seems clear enough that Hume regarded the desire of the rich and propertied to maintain the power that their riches and possessions afford them, as well as the desire of those who esteem the rich and propertied to acquire such power for themselves, to be the reason why an 'encrease in riches and possessions' in any society naturally leads to the establishment of 
government. For, on the one hand, those who are comparatively poor and possessionless see an opportunity to increase their power, while, on the other, those who are already rich and propertied see an opportunity to further increase their dominion over others. As the riches and possessions on offer are limited, these two interests are in conflict. And since Hume thinks that conflicts between passions naturally tend to obscure our judgements, such that we prefer what is near and at hand to the remote goods that obeying the laws of justice guarantees us (T 3.2.7, SBN 534-9), the establishment of some sort of civil authority becomes 'absolutely necessary': both to enforce the laws of property possession, and to decide any disputes over what those laws require (T 3.2.7, SBN 534-9).

It is perhaps not very surprising that Hume sees avarice and ambition at the root of the need for government. More notable, in this regard, is his detached "anatomical" method of analysing these phenomena. ${ }^{55}$ My purpose in sketching out Hume's main moves, however, is to suggest that the complexity of his explanation of the desire for riches and property - an explanation that employs ideas from across the whole of Book Two, and relies heavily upon his key conceptual devices: sympathy, comparison, and double relations of ideas and impressions - can be seen as evidence that his philosophy of the passions was primarily designed to account for this passion; rather than it being fortuitous that Hume's association-driven account of the mechanisms of our passions just happens to be able to explain why an increase in material wealth necessitates the establishment of political authorities, and to do so in a painfully precise manner.

One way to confirm this suspicion is to pay attention to those points where Hume confesses to find special difficulty in accounting for certain phenomena within his explanatory system. Of particular note here is his observation that ' $[\mathrm{t}]$ he passions of love and hatred are always followed by, or rather conjoin'd with benevolence and anger' ( $\mathrm{T}$ 2.2.6.3, SBN 367). The observation itself is plain enough, but, as Hume laments, it does not 'quadrate exactly with the principles that we would endeavour to establish' ( $\mathrm{T}$ 2.2.6.2, SBN 366), namely, his theory that love and hatred originate from a double relation of ideas and impressions, just as pride and humility do. For, insofar as love and hatred do arise in the same manner as pride and humility, Hume is unable to explain why love and hatred, unlike pride and humility, 'are not completed within themselves, nor rest in that emotion, which they produce, but carry the mind to something farther' (T 2.2.6.3, SBN 367).

Instead Hume is forced to either (1) concede that 'love is nothing but the desire of happiness to another person, and hatred that of misery' (T 2.2.6.4, SBN 367), which would make these passions 'direct' passions, on his system; or (2) to assert that love, as he has accounted for it, is conjoined with a separate passion of benevolence, and hatred with a separate passion of anger, 'by the

55 See here Tolonen, 1-40. 
original constitution of the mind' (T 2.2.6.6, SBN 368). Hume chooses (2). Yet, in doing so, he must concede that our benevolence towards those whom we love does not arise from a prior perception of the pleasure that our benevolent actions will cause them, nor does our anger towards those whom we hate arise from an appreciation of the pain that our hateful actions will cause them ( $\mathrm{T}$ 2.2.6.5-6, SBN 367-8). Instead these passions inexplicably arise whenever we feel love or hatred towards someone. This, however, requires Hume to posit that benevolence and anger are 'direct' passions that are not caused by perceptions of pleasure or pain (T 2.3.9.8, SBN 439); a move which complicates his initial description of 'direct' passions as those that 'arise immediately from good and evil, from pain or pleasure' (T 2.1.1.4, SBN 276).

Elizabeth Radcliffe has argued that Hume's analysis of loving benevolence and hateful anger into sets of distinct impressions is a deliberate rejection of Francis Hutcheson's account of the nature of moral love and hatred. ${ }^{56}$ In particular, of Hutcheson's providentialist explanation of moral love and hatred the products of an innate moral sense. ${ }^{57} \mathrm{I}$ cannot argue the point here, but I think that a similar thing is true of Hume's account of what he calls 'the mixture of benevolence and anger with compassion and malice' (T 2.2.9, SBN 381-9). Here too we find that Hume faces systematic explanatory difficulties in accounting for morally salient other-directed passions. In particular, Hume must explain why our sympathising with the sufferings of strangers often leads us to love them and act benevolently - rather than to hate them, as his double relation theory predicts we should (T 2.2.9.11, SBN 384-9). Hume's solutions here require him to stretch his system of the passions to the limits of its credibility, but, whatever their merits, I think that it is safe enough to assert that Hume intended his arguments on this head to oppose Hutcheson's explanation of compassionate benevolence as the product of an innate 'public sense', and his providentialist denial of genuinely disinterested malice. ${ }^{58}$

What I further maintain, however, is that the difficulties that Hume faces in explaining these morally salient other-directed passions are evidence that his intentions in doing so were secondary ones. More precisely, we find that Hume repeatedly faces difficulties in accounting for benevolent passions within his system of the passions because that system was originally designed to account for the self-interested passions at the origin of civil government. This is not to say, to be clear, that Hume's attempt to account for benevolent concerns within his system of the passions is less important than his attempt to account for the passionate conflicts engendered by riches and property. My claim, rather, is that Hume's chief conceptual devices - sympathy, comparison, and double relations of ideas and impressions - were originally invented to

56 See here Elizabeth S. Radcliffe, "Love and Benevolence in Hutcheson's and Hume's Theories of the Passions" British Journal for the History of Philosophy, 12(4) (2004): 631-653.

57 See here also Taylor, 1-31; Merivale, 49-69.

58 Merivale makes similar points, although he sees Hume's chief target as Joseph Butler. See Merivale, 49-50. 
the end of explaining the origin of government, and only later put to the purpose of explaining our natural benevolence. This is why - I contend - we find that Hume's system of the passions, considered as a system, is so wellsuited to explaining the origin of avarice and ambition, and so ill-suited to explaining the origins of our benevolent concerns for those around us.

Reading Hume's philosophy of the passions as having been shaped by primary and secondary intentions helps to explain some of the distractedness of Book Two. Hume's ad hoc introduction of 'blended' passions into his theory of love and hatred, and his inclusion of benevolence and anger amongst the 'direct' passions, can both be understood as his making adjustments to a system of the passions that he originally invented for a purpose other than accounting for our natural benevolence. Neither of these moves is incompatible with his general system, but both are necessary to render benevolence explicable. As such, one feels that if Hume had begun designing his system of the passions with the intention accounting for both the conflicts engendered by riches and property and our natural benevolence, he could have built these adjustments into his system from the outset. Indeed, it is arguable that the main conceptual adjustments that Hume makes in the Dissertation serve exactly this purpose. ${ }^{59}$

At the same time, reading Hume's philosophy of the passions as the product of two distinct intentions allows us to ask whether there is an underlying order to Book Two; such that Hume might be seen to have some further end in mind when explaining both the selfish origin of government, as well as our natural benevolence, within the same system of the passions. I am inclined to believe that Hume did have a larger design for his philosophy of the passions, although I admit that my thoughts here are rather speculative.

Namely, it seems to me that insofar as Hume was concerned to explain the psychology behind why government becomes 'absolutely necessary' once a society is affluent, he was concerned to do so without supposing any essential differences between humans and animals. Instead what Hume attempts to show is that all the passions he draws upon to explain violent competition for riches and possessions, including the will, are of the same nature in animals, and arise from the same principles: 'making a just allowance for our superior knowledge and understanding' ( $\mathrm{T}$ 2.1.12.5, SBN 326). Thus each of the three parts of Book Two ends with Hume observing that the phenomena he has just examined are of the same nature in animals, and are 'excited by the same causes as in human creatures' ( $\mathrm{T}$ 2.3.9.32, SBN 448). Of pride and humility', ends with the section ' $O f$ the pride and humility of animals' (T 2.1.12, SBN 324-8); 'Of love and hatred', with the section 'Of the love and hatred of animals' (T 2.2.12, SBN 397-8); while 'Of the will and direct passions' ends with Hume deciding to "wave (sic) the examination of the will and direct passions, as they appear in animals; since nothing is more evident, than that they are of 
the same nature, and excited by the same causes as in human creatures' ( $\mathrm{T}$ 2.3.9.32, SBN 448).

Without wanting to say too much about why Hume sought to do this, I think it is reasonable to believe that Bernard Mandeville was a key influence here. For Mandeville himself had held that:

the Fitness of Man for Society, beyond other Animals, is something real; but that it is hardly perceptible in Individuals, before great Numbers of them are joyn'd together, and artfully manag'd. Secondly, that this real Something, this Sociableness, is a Compound, that consists in a Concurrence of several Things, and not in any one palpable Quality, that Man is endued with, and Brutes are destitute of. ${ }^{60}$

In particular, I think that Hume - following Mandeville - sought to trace the origins of human sociability (and especially the establishment of civil government) to qualities of human nature that we share we with animals. But that - unlike Mandeville - his aim in doing so was not to debase human nature to the level of animals, but to develop a theory of human sociability that an impartial moralist, arguing only from what they can observe, could accept as probably true. ${ }^{61}$

So far as this was part of Hume's design when first developing his system of the passions, we can also see this intention operating behind his attempt to account for our natural benevolence. More precisely, it would seem that Hume's desire to account for benevolent behaviour within the same system of the passions that he had designed to account for the establishment of civil government was also part of an attempt to trace the origins of human sociability to qualities that we share with animals. Towards this point, it is notable that Hutcheson had attributed our benevolence towards those whom we love for their moral qualities, and our good-will towards those we pity, to essential differences between human and animal natures, in the form of innate moral and public senses. ${ }^{62}$

What Hume hoped to gain from this impartial presentation of mankind's sociable qualities is a question unto itself. Still, I think it safe to conclude that the unifying intention behind Hume's philosophy of the passions is to trace the origins of human sociability to qualities that we share we with animals. Hume achieves this by arguing that his explanations of the desire for riches and possessions, as well as benevolence, appeal only to passions and principles that can be found to operate throughout 'the whole sensitive

60 Bernard Mandeville, The Fable of the Bees or Private Vices, Publick Benefits, 2 vols., ed. F.B. Kaye (Indianapolis: Liberty Fund, 1988), vol 2, 209-10.

61 For more on this point see P.J.E. Kail, "The Sceptical Beast in the Beastly Sceptic: Human Nature in Hume", Royal Institute of Philosophy Supplement, 70 (2012), 219-31.

62 Francis Hutcheson, An Essay on the Nature and Conduct of the Passions and Affections, with Illustrations on the Moral Sense, ed. Aaron Garrett (Indianapolis: Liberty Fund, (2002), 90. 
creation' ( $\mathrm{T}$ 2.2.12.1, SBN 397); such that '[e]very thing is conducted by springs and principles, which are not peculiar to man, or any one species of animals' (T 2.2.12.1, SBN 397).

But, on second thoughts, how safe is this conclusion? For if such an intention is supposed to underlie the whole of Book Two, how then ought we to understand Hume's account of curiosity, with which he concludes his account of the passions? Hume's treatment of curiosity, or more exactly, of 'the love of knowledge, which displays itself in the sciences' (T 2.3.10.11, SBN 453 ) is notable for sitting somewhat apart from the rest of Hume's theory of the passions. ${ }^{63}$ Whereas parts one and two of Book Two end with an examination of analogous animal passions, part three ends with a waiver of such analogies regarding 'the will and direct passions, as they appear in animals' ( $\mathrm{T}$ 2.3.9.32, SBN 448; my italics) and instead concludes with an account of 'curiosity, or the love of truth' (T 2.3.10, SBN 448-54). Clearly Hume did not think that a love of knowledge was common to man and beast, yet such scientific curiosity is obviously something that renders human beings sociable creatures. Thus it would seem, prima facie, that this part of our sociable nature, our love truth, is explained by some quality of human nature that marks a difference in kind between human beings and animal natures. Namely, an innate desire to know. Indeed, this had been the standard position on the nature of curiosity since at least Aristotle, all the way up to Hobbes and beyond. ${ }^{64}$

Nor is this the only interpretive problem posed by Hume's account of curiosity. For it would seem that Hume realised rather late in the game that he ought to examine curiosity within his theory of the passions. In fact he opens his account of this passion with the claim that:

methinks we have been not a little inattentive to run over so many different parts of the human mind, and examine so many passions, without taking once into the consideration that love of truth, which was the first source of all our enquiries. 'Twill therefore be proper, before we leave this subject, to bestow a few reflections upon that passion, and shew its origin in human nature. 'Tis an affection of so peculiar a kind, that t'would have been impossible to have treated of it

63 Hume distinguishes between 'the love of knowledge, which displays itself in the sciences' and 'a certain curiosity implanted in human nature, which is a passion derived from a quite different principle' ( $\mathrm{T} 2.3 .10 .11, \mathrm{SBN} 453$ ). I take this second sort of curiosity to be a mode of what Hume calls the 'original instinct' by which the mind 'tends to unite itself with the good, and to avoid the evil' (T 2.3.9.2, SBN 438). In this case the good desired is the pleasant feeling of stable beliefs, while the evil to be avoided is the painfulness of uncertainty (see here T 2.3.10.12, SBN 453-4). The expression of this desire as a desire to know may be unique to humans (but this is far from clear, animals can be quite inquisitive) but the principle from which it is derived is surely common to both, at least by Hume's lights.

64 For a general overview here see Lorraine Datson and Katharine Park, Wonders and the Order of Nature, 1150-1750 (New York: Zone Books, 1998). 
under any of those heads, which we have examin'd, without danger of obscurity and confusion.

(T 2.3.10.1, SBN 448)

That Hume originally intended to include an account of curiosity within his theory of the passions and then simply forgot to do so is unbelievable. Yet that Hume did not have curiosity in mind when first developing his theory of the passions, and only came to see the importance of accounting for it after having already formulated his division of the passions into the 'direct' and 'indirect' would be entirely in keeping with the nature of Book Two. In fact I am inclined to believe that Hume's skeptical crisis at the end of Book One, which he attempts to resolve by appealing to both curiosity and ambition (see T 1.4.7.12-3, SBN 270-2), brought it home to him that he would need to account for what he calls 'the love of knowledge, as it displays itself in the sciences' within the same system of the passions that he had already developed to account for ambition.

Could it be, then, that Hume's late need to provide an account of curiosity throws out his general project of tracing the origins of human sociability to qualities that we share we with animals? Maybe. But more likely not. Again I cannot argue the point in detail, but I think that if we attend closely to Hume's account of 'the love of knowledge, which displays itself in the sciences' then we find that Hume attempts to show that this passion 'is conducted by springs and principles, which are not peculiar to man, or any one species of animals' (T 2.2.12.1, SBN 397).

Notable here is that Hume's first move is to assert that curious endeavour is not a desire for knowledge 'merely as truth, and that 'tis not the justness of our conclusions, which alone gives the pleasure' of discovering what we believe to be truths ( $\mathrm{T}$ 2.3.10.2, SBN 448-9). Rather, Hume compares the nature of curiosity to that of hunting, insofar as the 'principal foundation of the pleasure' that we derive from curious endeavour is 'not deriv'd originally from the end, but merely from the action and pursuit' (T 2.3.10.7, SBN 451). At the same time, however, the pleasure of the chase is not enough, Hume thinks, to keep us focused on our game, either when we hunt for sport or for knowledge. Instead, 'these actions must be attended with an idea of utility, in order to their having any effect upon us' (T 2.3.10.8, SBN 451-2). Such ideas of utility, Hume argues, are the product of our sympathizing with those whom we believe will benefit from our pursuits. A sympathy that even if rather 'remote', still serves to 'fix our attention' on the object of pursuit, be it a stag, or the principles of human nature (T 2.3.10.6, SBN 450-1).

Hume's explanation of the desire for knowledge as arising from the 'same principles' ( $\mathrm{T}$ 2.3.10.9, SBN 452) as the desire to hunt can be read as an attempt to explain this uniquely human passion using principles found to operate throughout 'the whole sensitive creation' (T 2.2.12.1, SBN 397). 
Towards this point, it is pertinent that Hume had previously observed, when examining the love and hatred of animals, that:

sympathy, or the communication of passions, takes place amongst animals, no less than amongst men ... Every one has observ'd how much more dogs are animated when they hunt in a pack, than when they pursue their game apart; and it is evident that this can proceed from nothing but sympathy. 'Tis also well known to hunters, that this effect follows to a greater degree, and even in too great a degree, when two packs, that are strangers to each other, are join'd together. We might, perhaps, be at a loss to explain this phænomenon, if we had not experience of a similar in ourselves.

(T 2.2.12.6, SBN 398)

On a surface level reading of this passage the similar experience that we have is of hunting for sport with strangers. Yet on deeper reading, one that is justified by the close analogy that Hume draws between hunting and curiosity, we can understand Hume as referring to the disparate factions of the republic of letters, collectively searching after truth, sometimes with too much zeal. So far as this is a good reading of the intentions behind Hume's account of curiosity, we can conclude that Book Two - all of it, not just some of it - is unified by the intention to trace the origins of human sociability to qualities that we share we with animals.

But still we cannot rest easy. For it is at least arguable that because Hume denies that the love of truth is an innate desire to know - and instead holds that this passion arises from a conjunction of the 'same principles' that produce the desire to hunt - Hume obscures his original distinction between passions that are 'indirect' and those that are 'direct.' For what curiosity turns out to be is a 'direct' passion for entertainment, one that is indifferent to its objects, so long as they are entertaining, but which indirectly becomes a love for truth 'itself' through what Hume vaguely describes as 'the natural course of the affections' (T 2.3.10.7, SBN 451): a course which includes our sympathising with the beneficiaries of our discoveries, be they strangers, friends, or enemies.

It is with good reason then that Hume describes curiosity as 'an affection of so peculiar a kind, that t'would have been impossible to have treated of it under any of those heads, which we have examin'd, without danger of obscurity and confusion' (T 2.3.10.1, SBN 448). For the 'love of knowledge, as it displays itself in the sciences' makes no neat fit within a system that begins with the assertion that ' $[w]$ hen we take a survey of the passions, there occurs a division of them into direct and indirect' (T 2.1.1.4, SBN 276). Instead curiosity, properly understood, is both. It is a 'blended' direct-indirect passion that threatens throw the rest of his explanatory system into 'obscurity and confusion. 
As such, what we ultimately find is that while Hume can explain the origin of scientific curiosity using principles that he had already observed to operate in animals, his doing so threatens the coherence of the major conceptual distinction upon which his entire system rests. This, to my mind, is Book Two in a nutshell: an inquiry into the true nature of human sociability that unravels from the pull of its own explanatory ambitions.

\section{Conclusion}

'Never literary attempt was more unfortunate than my Treatise of Human Nature'65, Hume wrote in 1776, towards the very end of his life. 'It fell deadborn from the press, without reaching such distinction, as even to excite a murmur among the zealots' 66 . The sixty-five year old Hume blamed the stillbirth (in his opinion) of his Treatise on his youthful indiscretion, in going to press to early' ${ }^{67}$, at the age of twenty-six. Indeed, not long before, Hume had instructed that all further editions of his Enquiry concerning Human Understanding and Enquiry concerning the Principles of Morals were to come with an 'advertisement' to the effect that these works 'may alone be regarded as containing his philosophical sentiments and principles' ${ }^{68}$. For the Treatise, he admitted there, was a 'juvenile work', which he had 'projected before he left college, and which he wrote and published not long after' 69 .

A 'juvenile work' is a good description of Book Two. If anything it is more true for Book Two than for Book One or Book Three. Hume's youthful explanatory incontinence, I think, goes a long way to explaining why Book Two was initially met with such disdain, even by Hume's champions. Although now, almost seventy years of scholarship later, we have a better sense of the value and importance of Book Two as a part of Hume's science of human nature. An even greater appreciation, perhaps, than that which the later Hume had for Book Two, given that he never gave his philosophy of the passions the kind of thorough re-working that he afforded the other books of the Treatise.

My aim in the above has been to reconcile our present sense of the philosophical importance of Book Two with the fact that it is indeed a juvenile work when read on its own terms. I have argued that Hume's philosophy of

65 David Hume, "My Own Life", in David Hume, An Enquiry Concerning Human Understanding, ed. Stephen Buckle (Cambridge: Cambridge University Press, 2007) (My Own Life), 215.

66 Hume, My Own Life, 216.

67 Hume, My Own Life, 217.

68 See David Hume, An Enquiry Concerning Human Understanding, ed. Stephen Buckle (Cambridge: Cambridge University Press, 2007), 2.

69 Hume, An Enquiry Concerning Human Understanding, 2. 
the passions is the product of three distinct intentions: an attempt to account for the establishment of government, for our natural benevolence, and to trace human sociability back to qualities that are common to the whole of sensitive creation. Accounting for the origins of both government and benevolence was of equal importance to Hume, but I have argued that his accounting for the origin of government was the primary concern of Book Two, and that Hume found himself having to stretch his theory of the passions to accommodate benevolence. Further, I have suggested that Book Two has a distinctive unity of purpose when the first and second of these intentions are subsumed under the third, but that, by the same measure, Hume's desire to place human sociability on a continuum with animal sociability ultimately threatens the coherence of his whole system. We ought not lament this, however. Rather, if we are to understand the distracted and distracting nature of Hume's philosophy of the passions - which is as much a part of its character as its ambitions to systematicity - then perhaps the best way to think of Book Two is as an unstable explanatory compound: a work that fizzes through a series of different explanatory designs, before dissolving into the river of Hume's mature philosophy. 